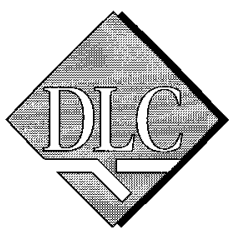

\title{
The East Greenland volcanic rifted margin - onshore DLC fieldwork
}

\author{
C. Kent Brooks and field parties
}

In accordance with the main objectives of the Danish Lithosphere Centre (DLC) research plan (Larsen, this report), the main onshore field work in East Greenland in 1995 had the following aims: (1) to collect from the entire exposed sequence of lavas in the Blosseville Kyst region and connect up existing work in the Scoresby Sund region with that around Kangerlussuaq; (2) to make comprehensive collections from the dyke swarms, establish their temporal relationships and to describe the structures associated with them; (3) to collect material for fission track dating from as extensive an area as possible, with the aim of documenting the timing and magnitude of uplift before, during and subsequent to the volcanic episode. In addition, a number of other tasks were carried out taking advantage of the logistic apparatus already established. In particular, a Geological Survey of Denmark and Greenland (GEUS) project, supported by DLC and Danish Oil and Gas Production A/S (DOPAS), was carried out in the Kangerlussuaq sedimentary basin and is expected to produce results of major interest to DLC (see M. Larsen et al., this report).

In summary, the main objectives of this research are to document the chemical changes of the volcanic parents (magmas), to determine both the absolute and relative timing of the different magma types, and to correlate these events with both stretching and vertical movements within the Earth's crust. This ambitious programme will take some years of laboratory studies to realise and includes comprehensive major element, trace element and isotopic studies. A comprehensive radiometric dating programme is being carried out in collaboration with R. A. Duncan, Oregon State University.

Field work in 1995 was carried out from a base at the airstrip at Sødalen at the head of Miki Fjord (Fig. 1) and covered an area of approximately $50000 \mathrm{~km}^{2}$. It involved 34 scientists (see Appendix) and two helicopters for the period 13 July until 15 September. All the main objectives of the expedition were achieved, including visits to areas hitherto regarded as inaccessible.

The basalts of the Blosseville Kyst region form a mountainous area, which includes the highest mountains within the Arctic Circle. During field work in 1995, a region of about $30000 \mathrm{~km}^{2}$ between Miki Fjord and Sortebra (Fig. 1) was investigated in a number of large composite sections, designed to cover the entire lava stratigraphy in both coastal and inland areas, and also to cover possible north-south variations. The sections were based on information obtained by the aerial photography acquired in 1994 (H. C. Larsen et al., 1995), where colour stereo images were obtained covering approximately 1600 line-kilometres of valley and fjord walls. From this it was determined that the succession reaches a total thickness of at least $6 \mathrm{~km}$, probably closer to $7 \mathrm{~km}$, in the Sortebræ area (Fig. 1). A number of sampling profile sites were identified spanning the whole lava succession and ensuring completeness of the sample coverage. During the summer of 1995 a further 650 linekilometres of airborne stereo photographs were acquired, largely in the plateau basalts but also covering other aspects of DLC's work in the area.

Prior to the 1995 field season it was known that the onshore lavas between latitudes $68^{\circ}$ and $70^{\circ} \mathrm{N}$ can be divided into three groups (Wager, 1947; Brooks et al., 1976; Brooks \& Nielsen, 1982), which are distinct both in the field and petrologically. We have used this conventional grouping pending their formal redescription: the lower basalts, the plateau basalts and youngest Prinsen af Wales Bjerge basalts.

\section{The lower basalts}

Previous studies (Brooks et al., 1976; Nielsen et al., 1981) have shown that the lithology of the lower basalts succession, which outcrops in the area between Kangerlussuaq and Nansen Fjord, is very different from the plateau basalt succession to the north, as it predominantly consists of compound flows with numerous clastic horizons. Most notable is the occurrence of highly magnesian lavas (picrites) which have an enriched geochemical signature.

The lower basalts succession was studied and sampled by a group of four scientists from field camps using helicopter support. In addition to extreme topography, the region presents numerous problems due to the pervasive alteration in this deep level of the lava pile, the restricted continuity along strike of many of the units and the presence of numerous sills which completely obscure the stratigraphy in some areas. Fourteen profiles, covering $c .5000 \mathrm{~m}$ of 


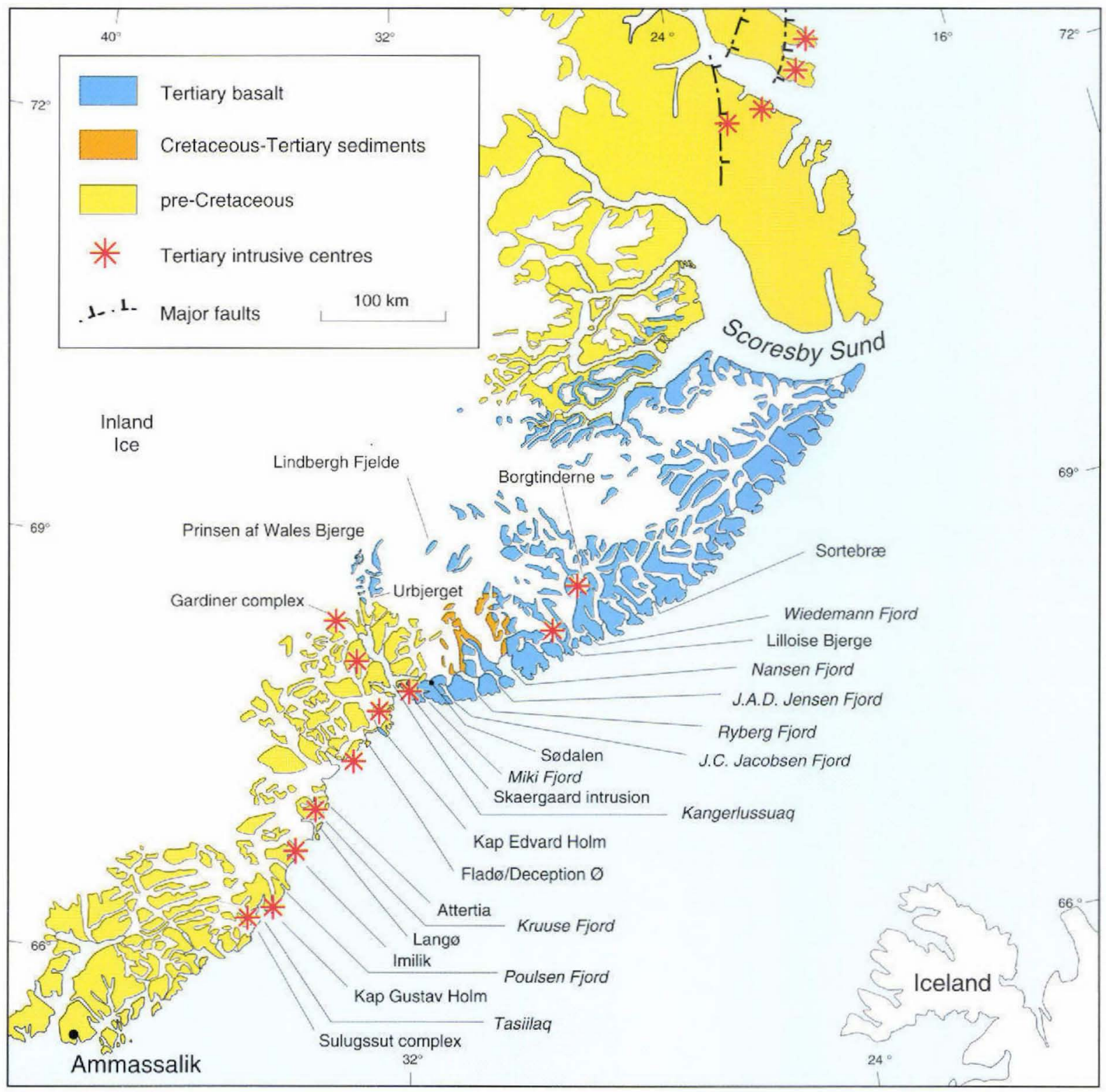

Fig. 1. East Greenland showing the extent of the Tertiary basalts and related rocks. The Blosseville Kyst is the stretch of coastline between Kangerlussuaq and south of Scoresby Sund.

stratigraphy, in Miki Fjord, J. C. Jacobsen Fjord, Ryberg Fjord, J. A. D. Jensen Fjord and Nansen Fjord (Fig. 1) were studied in detail and the entire succession was sampled.

The lower basalts are traditionally regarded as comprising the Vandfaldsdalen and Miki Formations (Soper et al., 1976) with the transition to the overlying plateau basalts marked by a prominent tuff sequence, known as the 'Main Tuffs' (Wager, 1947) or Hængefjeldet Formation (Soper et al., 1976; Nielsen et al., 1981). This division was established in the western part of the area (i.e. in Miki Fjord and J. C. Jacobsen Fjord), the eastern part being relatively un- known. It was possible to follow the stratigraphy as far as Ryberg Fjord, although the thickness of the Miki Formation appears to thin considerably east of J. C. Jacobsen Fjord. At the same time, the Vandfaldsdalen Formation, which overwhelmingly consists of lava flows in the west, with subordinate volcanogenic sediments, pillow breccias (Fig. 2) and quartzitic sandstones, becomes almost exclusively hyaloclastite breccias in the east. This facies change indicates that during volcanism the depositional basin deepened towards the east.

It proved difficult to correlate eastwards of Ryberg Fjord. 


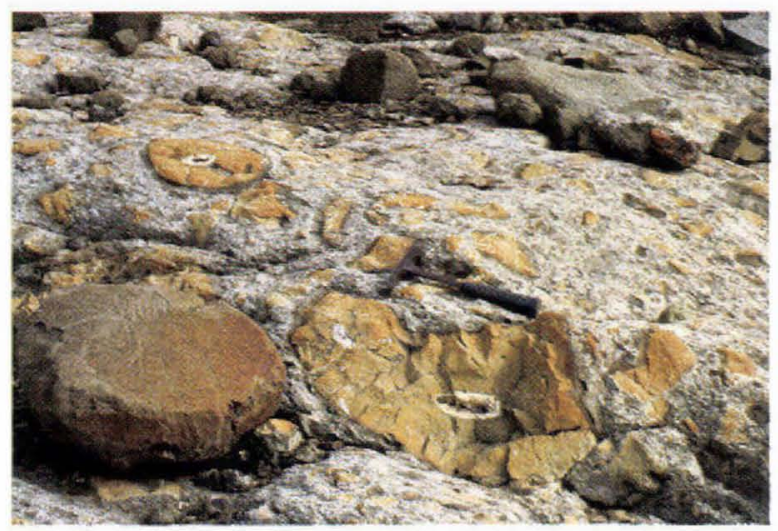

Fig. 2. Pillow breccias in the lower basalts of Sødalen. Wellformed pillows and pillow fragments with glassy (now altered) margins are enclosed in altered hyaloclastite lapilli tuff. While some of the lower basalts are subaqueous, the bulk are subaerial.

There are many sills and the succession in J. A. D. Jensen Fjord is dramatically different from the portion of the succession to the west. Lowermost in the sequence at this locality are thick flows, $10-15 \mathrm{~m}$ thick, interbedded with reddened and locally scoriaceous deposits. This sequence is overlain by $4-15 \mathrm{~m}$ thick olivine-pyroxene-phyric flows. Plagioclase-olivine glomerophyric flows dominate the upper portions of the J. A. D. Jensen Fjord section. These latter units may be part of the plateau basalts, although a specific correlation cannot be made at this time.

\section{The plateau basalts}

Throughout the field season $2-4$ field teams worked in the plateau basalts. Nearly $30 \mathrm{~km}$ of continuous profile was sampled, amounting to about 2200 samples. Special studies of the zeolite zonation and of laterite horizons were also carried out, the latter with a view to reconstruction of palaeo-climates.

The base of the succession is exposed in the southern part of the region, where volcanogenic sediments, interpreted as lahars, are present over large areas and overlie basement gneisses (which have a very irregular topography) or Cretaceous-Paleogene sediments of the Kangerdlugssuaq Group (Nielsen et al., 1981). The correlation with the lavas and volcanoclastic rocks south of Nansen Fjord (lower basalts, Nielsen et al., 1981) is not evident and awaits further photogrammetric studies. However, field observations using distinctive lithologies, such as phenocryst content and size, have allowed a tentative correlation to the north with the earlier established formations in the Scoresby Sund region (L. M. Larsen et al., 1989). Lavas lithologically similar to those of the Milne Land, Geikie Plateau, Rømer Fjord and Skrænterne Formations are present in large parts of the investigated region. The Geikie Plateau and Rømer Fjord
Formations are thickest in the coastal areas, and the Rømer Fjord Formation appears to wedge out completely in some inland areas. Several horizons of olivine-phyric magnesian lavas (Fig. 3) were found, especially in the lower part of the succession. The uppermost formation, the Skrænterne Formation, is mostly above exposure level in the southeastern half of the region.

The Skrænterne Formation, previously thougt to be the uppermost unit within the plateau basalts, was locally found to be overlain, without any apparent unconformity, by a few, very fresh lavas of an alkaline nature. At present it is not known whether there is any correlation of these flows to the alkaline lavas within the Prinsen af Wales Bjerge (see below).

Eruption sites were found at several localities in both coastal and inland areas, and in both low and high parts of the succession.

Regional studies of the zeolites suggest that a well developed pattern of zeolite zones exists. The zones dip with the basalt stratigraphy, indicating that low-grade metamorphism pre-dated tectonism in the lava pile.

A number of tilted fault blocks were identified in a broad zone along the coast extending from $30 \mathrm{~km}$ to more than $100 \mathrm{~km}$ inland. Along the coast the lavas dip seaward at up to $12^{\circ}$.

\section{The Prinsen af Wales Bjerge basalts}

These lavas overly the plateau basalts in a series of nunataks, known as the Prinsen af Wales Bjerge, north of the head of Kangerlussuaq (Figs 1 \& 4). They are reported to show irregular dips, in contrast to the plateau basalts, and to consist of alkaline types, in contrast to the uniformly tholeiitic character of the preceding volcanism (Wager, 1947; Anwar, 1955).

In 1995 a 2-man team collected detailed profiles in the nunataks north of inner Kangerlussuaq. Additional sites were visited by helicopter.

Wager (1947) believed the irregular dips of these lavas to represent near-vent facies. However, work in 1995 suggested that in some cases they are caused by draping of palaeo-river valleys cut into the top of the plateau basalts, although no unequivocal example of this interpretation could be found. The nunataks have an unusual rounded topography, which may reflect a pre-Pleistocene land-form. Glaciers draining the Inland Ice have sliced into this earlier configuration and have steep-sided margins. Exposures are poor above the present major glaciers.

At least in some cases, variable dips do represent the flanks of crater areas as suggested by Wager (1947). One of these structures was visited and found to contain a coarsegrained plutonic rock filling the central vent.

Anwar (1955) reported that the Prinsen af Wales lavas 


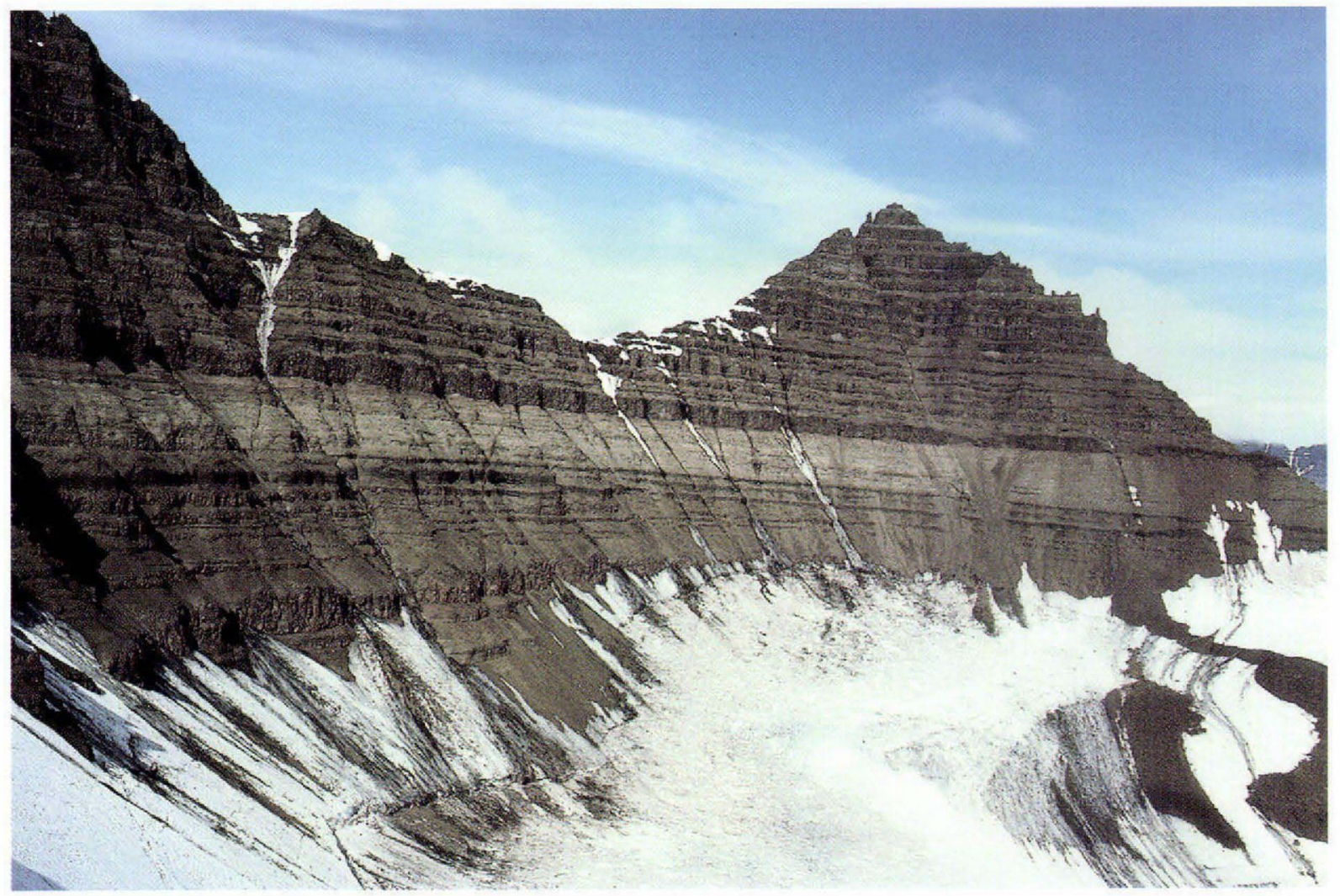

Fig. 3. Part of the plateau basalt succession from the Geikie Plateau Formation in the nunatak zone of Lindbergh Fjelde more than $100 \mathrm{~km}$ inland from the coast. The light grey series are picrites. The discovery of widespread high magnesian lavas will simplify the study of mantle melting processes during the evolution of the volcanic rifted margin. Photo: A. K. Pedersen.

are weakly alkaline and contrast compositionally with the underlying tholeiitic 'Plateau Basalts'. Pyroxene-phyric lavas are common and picritic and glassy types were observed. These lithologies are rare to absent in the plateau basalts, where plagioclase is the most common phenocryst phase.

The most westerly nunatak (Lindsay Nunatak in Fig. 4) was found to have picritic lavas at the top, underlain by fluvial sediments containing a coarse-grained conglomerate. Blocks from this conglomerate contain a wide variety of alkaline rocks, including some with eudialyte, a mineral known only from the Gardiner complex, although this is not thought likely to be the source. It is suggested that the conglomerate was deposited by westwards-flowing rivers, following the geomorphological reconstruction of Brooks (1979). These rivers may be those which carved the palaeovalleys in the Prinsen af Wales nunataks.

\section{Dyke swarms}

The East Greenland coast is famous for its impressive dyke swarm originally reported by Wager \& Deer (1938), which has been re-interpreted by Nielsen (1975), Nielsen \& Brooks (1981) and Myers (1980). The dyke swarm is intimately associated with a major coastal flexure and is an important part of the history of break-up of this part of the North Atlantic (e.g. Larsen, 1978).

DLC studies on the dyke swarm in 1995 were focused in particular on: (1) establishment of the time relationships between different generations of the dyke swarm; (2) establishment of any differences along the dyke swarm with relation to the assumed centre of a proto-Icelandic plume; (3) whether the segmentation described by Myers (1980) can be confirmed; (4) whether the chemical types already established in the Kangerlussuaq area (Nielsen, 1978; Gill et al., 1988) can be recognised in distal regions; and (5) the mechanism of flexuring.

An important question to answer is whether the North Atlantic opened by rift propagation from south to north (e.g. Larsen, 1988) or has opened from the hot-spot centre due to stresses caused by the mantle plume (e.g. Brooks, 1973).

With these aims in mind detailed profiles across the dyke swarm were made at six selected localities: J. C. Jacobsen 


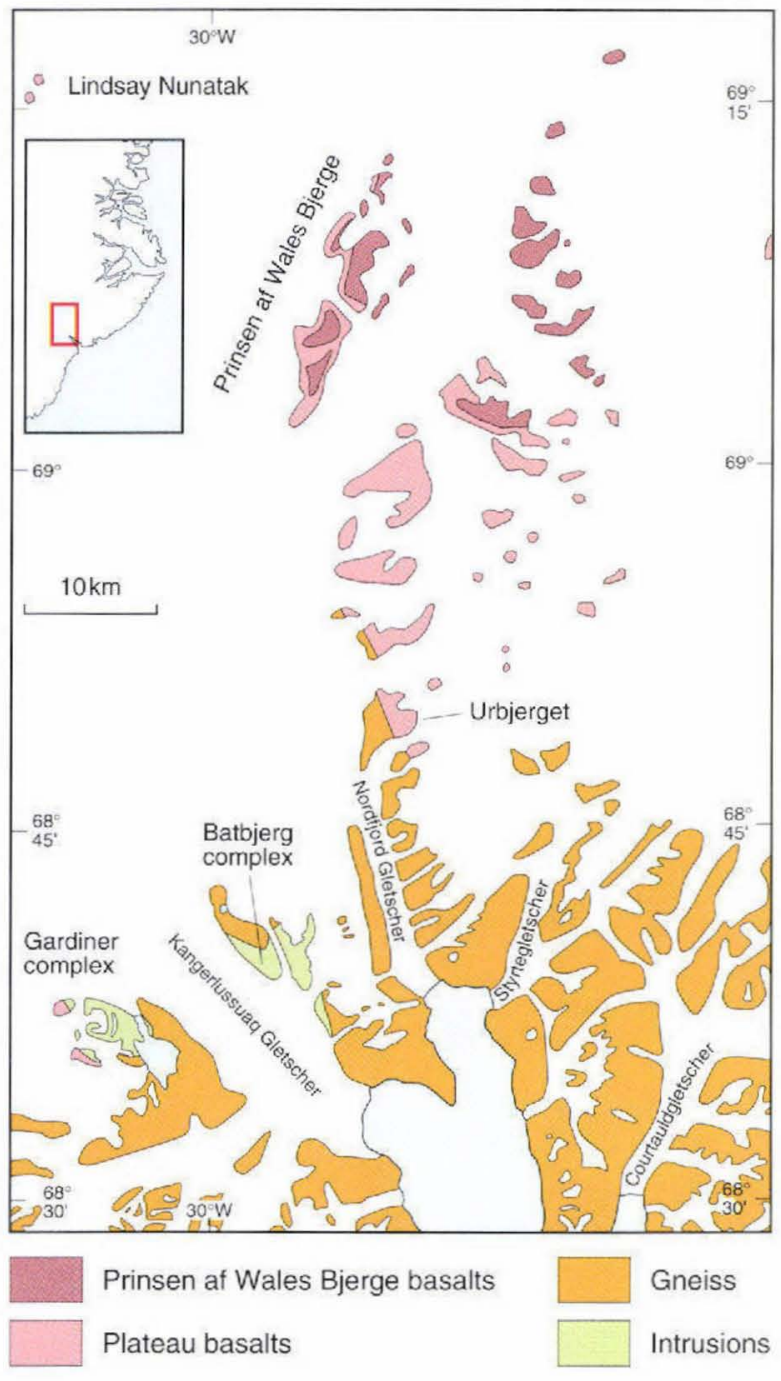

Fig. 4. Sketch of the area of the Prinsen af Wales Bjerge (after Wager, 1947). Note that the Batbjerg Complex is of Caledonian age.

Fjord, Kap Edvard Holm, Fladø, Deception Ø, Attertia and Lang $\emptyset$ to the south along the coast (Fig. 1). In addition, shorter excursions were made to outlying areas. Each transect was 10 to $20 \mathrm{~km}$ in length. J. C. Jacobsen Fjord lies in the east-west section of the coast to the east of Kangerlussuaq, the sector where some of the earlier studies were carried out (Nielsen, 1978). The other localities lie to the south, where the coastline is more north-south trending and the only previous work is the geochemical study of Gill et al. (1988) from Fladø. Kangerlussuaq is thought to form a triple junction, with the fjord forming the third arm or 'failed arm' (Brooks, 1973). Sampling was carried out in the interior of Kangerlussuaq and in the area of sediments to the north of Ryberg Fjord and J. A. D. Jensen Fjord.
Work ranged from broad regional studies to very detailed investigations. Detailed measurements of thicknesses and attitudes of the dykes over long profiles, perpendicular to the general trend of the outer coast, were carried out with the aim of quantifying the degree of magmatic extension. Data were collected in the six transects measuring 1700 dykes altogether. One profile alone (that on Langø) contains over 500 dykes (Fig. 5). In the course of this work, 208 rock samples were taken for chemical analysis (see below). It is clear that certain systematic changes are found along the coast. South of Kangerlussuaq there is a gradual clockwise rotation of the average strike from south to north and there appear to be at least three distinct sections, although it is not clear whether these correspond to the segments described by Myers (1980). In the area of Attertia, Myers' dyke clusters could not be identified.

The geochemically orientated studies used detailed mapping of reference areas of limited extent within each segment of the swarm, supplemented by reconnaissance work over larger areas. In the reference areas, all dyke relationships were recorded and complete sampling was carried out in order to establish the chronological sequence of geochemical types. Ultimately it should be possible, using chemical fingerprinting, to correlate these dykes with known lava types. A collection of samples was made of material thought to be suitable for the extraction of zircon or baddeleyite for radiometric dating of the dyke swarm.

Structural work, to determine the deformation style of the East Greenland margin during extension, was carried out as an integral part of the above mentioned projects. Drilling of selected dykes as well as gabbro bodies was carried out to obtain samples for palaeomagnetic studies to determine the degree of rotation of the dykes.

Observations made in areas of basement gneisses, sediments and basalts, and at seaward, middle and inner parts of the transects will give information on the modes of strain accommodation at various levels and locations within the margin. Most of the transects are located in areas of moderate rotation, but highly rotated areas are exposed at Nuuttuaq in Poulsen Fjord (just south of Imilik in Fig. 1) and Deception $\varnothing$. One of the major discoveries of the season was the discovery of major strike-slip faults perpendicular to the margin which appear to have served as accommodation zones during early stretching of the margin. They cut an early generation of dykes. Pseudotachylites, first discovered in 1994 in the Tasiilaq region to the south and recently confirmed to be Tertiary by ${ }^{40} \mathrm{Ar} /{ }^{39} \mathrm{Ar}$ dating (M. Storey, unpublished DLC data), were found to be common, particularly in association with this strike-slip faulting (Fig. 6). Major normal faults were found to be rare, but low-angle mafic sheets and bed-parallel slip indicate that low angle deformation is significant in the sediments in Sødalen and at Kap Edvard Holm. 


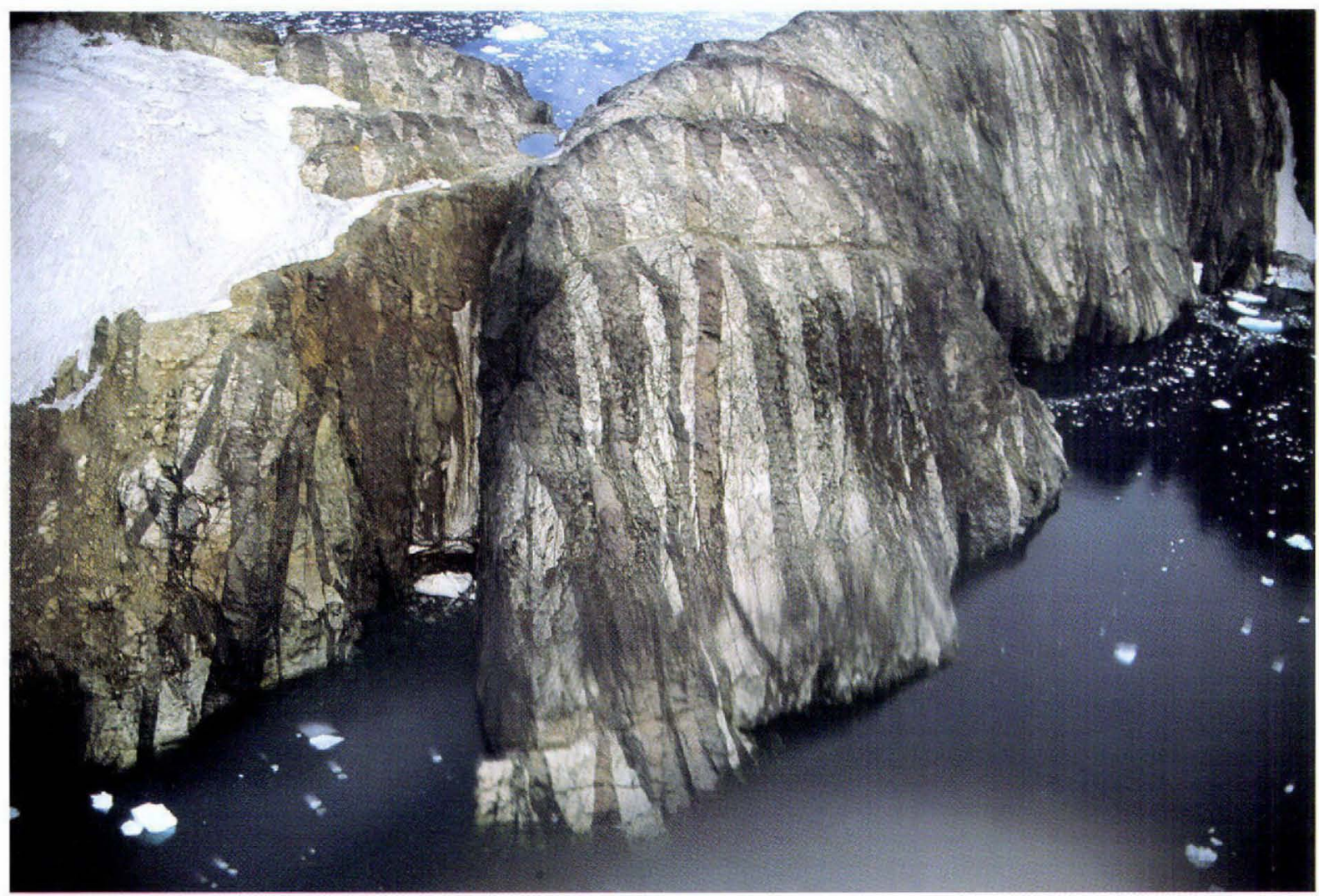

Fig. 5. The dyke swarm on Langø giving an impression of the difficulties of working this area.

\section{Sill complexes and macrodykes}

The Tertiary sill complex, hitherto almost undocumented, was sampled in a $50 \mathrm{~km}$ transect across the Kangerlussuaq sedimentary basin, where numerous sills intrude Cretaceous and Paleocene sediments and lavas. The accumulated thickness exceeds $1000 \mathrm{~m}$. Compositions represented are mainly diabases, with some picrites and ankaramites and a few syenites. They appear to include the earliest volcanism in the region and represent both lower basalts and plateau basalt compositions. Because they show less alteration than many of the lavas they are expected to place important constraints on magma compositions, especially of the lower basalts which are pervasively altered.

Mapping and sampling of macrodykes at Sødalen and Kramer $\varnothing$, which lies just to the west of the Skaergaard intrusion, were also carried out.

\section{Fission track project}

In order to quantify the extent and timing of vertical movements in the area, basement gneisses were collected for the separation of apatite. The samples were largely grouped in two major traverses: one parallel to Kangerlussuaq, the other perpendicular to the coast opposite Decep- tion $\emptyset$, about $100 \mathrm{~km}$ to the south. Samples were taken wherever possible from a range of altitudes from sea level up to about $2000 \mathrm{~m}$, although this was not possible on the southerly traverse. Previous work (Brooks, 1979, 1985; Gleadow \& Brooks, 1979) has shown that a major dome structure centred on Kangerlussuaq was probably raised about $50 \mathrm{Ma}$ ago and was succeeded by regional plateau uplift. Larsen (1990) showed this to be part of the regional margin uplift and to be compared with the conjugate European margin (Rohrman et al., 1995). Fission track dating will allow uplift rates and timing to be measured and eval-

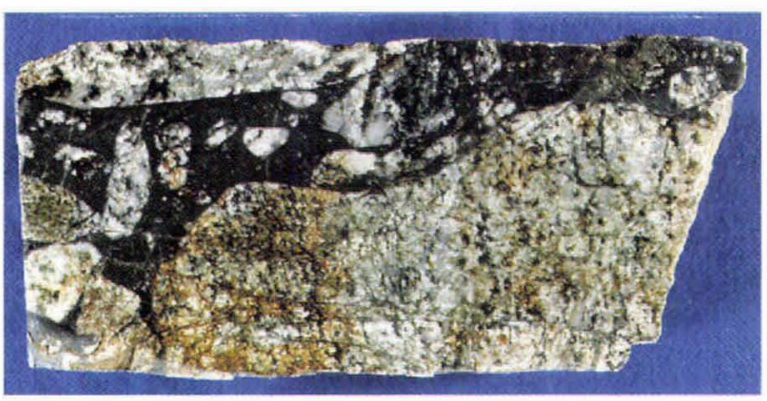

Fig. 6. Hand specimen of pseudotachylite. Sample is about $18 \mathrm{~cm}$ long. Photo: J. Lautrup. 
uated in the light of break-up events. The implications of the uplift history can be important to understanding the geodynamics of the area (e.g. Larsen \& Marcussen, 1992; Lawvers \& Müller, 1994).

\section{Gabbroic intrusions}

Gabbros are an important part of the oceanic crust and appear to have been intruded in abundance during the Tertiary break-up in East Greenland. The following gabbro intrusions were studied and sampled: Lilloise, Kruuse Fjord and the Imilik complex. Most of these studies were continuations of previous work, including that on the Imilik complex, where both older and younger bodies were identified in 1994. The older gabbros are heavily deformed and intruded by numerous dykes, whereas the younger are undeformed and only cut by the latest dyke generations. Material was collected for ${ }^{40} \mathrm{Ar} /{ }^{\beta 9} \mathrm{Ar}$ radiometric age determinations. The gabbros and other rock types at Lilloise Bjerge are of exceptional interest, as the complex is a very high temperature intrusion, which has not exchanged oxygen with its surroundings (Sheppard et al., 1977) and contains a primordial helium signature (Kelemen et al., 1991). It also lies close to the deduced track of the Icelandic plume centre (Lawvers \& Müller, 1994).

\section{Dykes with mantle nodules}

Brooks \& Rucklidge (1973) described a loose block from Wiedemann Fjord, near the Lilloise intrusion, which contained harzburgite mantle nodules alongside discrete nodules of kaersutite, diopside, salite, grey spinel and opaque spinel. These nodules represent one of the very few examples of such mantle nodules from the entire North Atlantic province and potentially contain valuable information about the nature of the underlying mantle.

In 1995 several N-S trending, nodule-bearing dykes on the eastern side of the head of the fjord and on the outer coast at Kap Ravn (which lies just west of Wiedemann Fjord) were discovered. These dykes are thin $(\sim 50 \mathrm{~cm}$ wide), but may be followed over long distances. Dyke margins are free of nodules and megacrysts, which are highly concentrated along the centres. The host rock is a kaersutite-rich lamprophyre, similar to many others in the area, and the nodules do not exceed about $3 \mathrm{~cm}$ in size. Kaersutite megacrysts are up to $4 \mathrm{~cm}$ across. Blocks containing numerous pyroxenite nodules were also found in a somewhat different host rock lithology.

\section{Other activities}

As part of the documentation of DLC, and in association with documentation of the Ocean Drilling Progam, film- ing was carried out by Aaron Woods (ODP, Texas A \& M University).

Acknowledgements. The 1995 programme was entirely dependent on the high skills of the helicopter and Twin Otter personnel from Greenlandair $\mathrm{A} / \mathrm{S}$ and from Flugfélag Norðurlands $\mathrm{H} / \mathrm{F}$, Akureyri, respectively. The personnel in the base camp and in particular, Troels Nielsen, DLC, who planned and directed the complex logistic operations, are thanked for constant and efficient support.

Appendix. Personnel involved in various aspects of the work are as follows:

Plateau basalts: A. K. Pedersen, L. M. Larsen W. S. Watt (University of Copenhagen, GEUS and DLC), M. Watt (Bornholms Museum), assisted for part of the time by M. Storey, S. Bernstein, C. Tegner and C. K. Brooks (University of Copenhagen and DLC), D. K. Bird, P. O'Day and P. Neuhoff (Stanford University, USA), and P. Kelemen (Woods Hole Oceanographic Institution, USA). Also present for a shorter period were J. Hopper (DLC), R. A Duncan (Oregon State University, USA) and Johann Helgasson (private consultant, Iceland). Studies of the laterites and zeolites were carried out by P. O'Day and P. Neuhoff, respectively.

Prinsen af Wales Bjerge: C. K. Brooks (University of Copenhagen and DLC), D. Bird, P. Neuhoff and P. O'Day (Stanford University, USA).

Lower basalts: C. E. Lesher, P. Thy and I. Ukstins (University of California, Davis, USA) and H. Hansen (University of Copenhagen and DLC).

Coastal dyke swarms and flexure: K. Hanghøj and M. B. Klausen, (DLC and University of Copenhagen), $O$. Svenningsen (DLC), J. Karson, D. Curewitz and L. Guenther (Duke University, USA).

Fjord dykes: P. M. Holm and G. Hoffmann Barfod (University of Copenhagen).

Dykes and sill complexes: S. Bernstein and C. Tegner (DLC), R. Wilson (University of Aarhus, Denmark), and P. Momme and P. Gisselø (University of Aarhus).

Gabbros: S. Bernstein and C. Tegner (DLC), D. Bird (Stanford University, USA) and P. Kelemen (Woods Hole Oceanographic Institution, USA).

Fission track sampling: C. K. Brooks (University of Copenhagen and DLC).

\section{References}

Anwar, Y. M. 1955: Geological investigations in East Greenland. Part V. The petrography of the Prinsen af Wales Bjerge lavas. Meddr Grønland 135 (1), 35 pp.

Brooks, C. K. 1973: Rifting and doming in southern East Greenland. Nature, Phys. Sci. 244, 23-25.

Brooks, C. K. 1979: Geomorphological observations at Kangerdlugssuaq, East Greenland. Meddr Gronland, Geosci. 1, 24 pp.

Brooks, C. K. 1985: Vertical crustal movements in the Tertiary of central East Greenland: a continental margin at a hot spot. $Z$. Geomorph. Suppl. 54, 101-117.

Brooks, C. K. \& Nielsen, T. F. D. 1982: The Phanerozoic development of the Kangerdlugssuaq area, East Greenland. Meddr Grønland, Geosci. 9, 30 pp. 
Brooks, C. K. \& Rucklidge J. C. 1973: A Tertiary lamprophyre dike with high pressure xenoliths and megacrysts from Wiedemanns Fjord, East Greenland. Contrib. Mineral. Petrol. 42, 197212.

Brooks C. K., Nielsen, T. F. D. \& Petersen, T. S. 1976: The Blosseville Coast basalts of East Greenland: their occurrence, composition and temporal variations. Contrib. Mineral. Petrol. 58, 279-292.

Gill, R. C. O., Nielsen, T. F. D., Brooks, C. K. \& Ingram, G. A.1988: Tertiary volcanism in the Kangerdlugssuaq region, E. Greenland: trace element geochemistry of the Lower Basalts and tholeiitic dyke swarms. In Morton, A. C. \& Parson, L. M. (ed.) Early Tertiary volcanism and the opening of the NE Atlantic. Spec. Publ. Geol. Soc. Lond. 39, 161-179.

Gleadow, A. J. W. \& Brooks, C. K. 1979: Fission track dating, thermal histories and tectonics of igneous intrusions in East Greenland. Contrib. Mineral. Petrol. 71, 45-60.

Kelemen, P. B., Kurz, M., Brooks, C. K. \& Bernstein, S. 1991: Trace element and $3 \mathrm{He} / 4 \mathrm{He}$ composition of the mafic/ultramafic Lilloise intrusion and related igneous rocks, North Atlantic Tertiary magmatic province, East Greenland. EOS 72, 536 only.

Larsen, H. C. 1978: Offshore continuation of East Greenland dyke swarm and North Atlantic Ocean formation. Nature $\mathbf{2 7 4}$ 220-223.

Larsen, H. C. 1988: A multiple and propagating rift model for the NE Atlantic. In Morton, A. C. \& Parson, L. M. (ed.) Early Tertiary volcanism and the opening of the NEAtlantic. Spec. Publ. geol. Soc. Lond. 39, 157-158.

Larsen, H. C. 1990: The East Greenland shelf. In Grantz, A., Johnson, L. \& Sweeney, J. F. (ed.) The Arctic Ocean region. The geology of North America L, 185-210. Boulder, Colorado: Geological Society of America.

Larsen, H. C. \& Marcussen, C. 1992: Sill intrusion, flood basalt emplacement and deep crustal structure of the Scoresby Sund region, East Greenland. In Storey, B. C., Alabaster, T. \& Pankhurst, R. J. (ed.) Magmatism and causes of continental breakup. Spec. Publ. geol. Soc. Lond. 68, 365-386.

Larsen, H. C., Brooks, C. K., Hopper, J. R., Dahl-Jensen, T., Pedersen, A. K., Nielsen, T. F. D. and field parties 1995: The Tertiary opening of the North Atlantic: DLC investigations along the east coast of Greenland. Rapp. Grønlands geol. Unders. 165, 106-115.
Larsen, L. M., Watt, W. S. \& Watt, M. 1989: Geology and petrology of the Lower Tertiary plateau basalts of the Scoresby Sund region, East Greenland. Bull. Gronlands geol. Unders. 157, $164 \mathrm{pp}$.

Lawvers, L. A. \& Müller, R. D. 1994: The Iceland hotspot track. Geology 22, 311-314.

Lindsay, M. 1935: Sledge. The British Trans-Greenland Expedition, 1934. London: Cassell, $342 \mathrm{pp}$.

Myers, J. S. 1980: Structure of the coastal dyke swarm and associated plutonic intrusions of East Greenland. Earth Planet. Sci. Lett . 46, 407-418.

Nielsen, T. F. D. 1975: Possible mechanisms of continental breakup in the North Atlantic. Nature 253, 182-184.

Nielsen, T. F. D. \& Brooks, C. K. 1981.The E Greenland continental margin an examination of the coastal flexure. J. geol. Soc. London 138, 559-568.

Nielsen, T. F. D., Soper, N. J., Brooks, C. K., Faller, A. M., Higgins, A. C. \& Matthews, D. W. 1981: The pre-basaltic sediments and the Lower Basalts at Kangerdlugssuaq, East Greenland: their stratigraphy, lithology, palaeomagnetism and petrology. Meddr Grønland, Geosci. 6, 25 pp.

Rohrman, M., van der Beek, P., Andriessen, P. \& Cloetingh, S. 1995: Meso-Cenozoic morphotectonic evolution of southern Norway: Neogene domal uplift inferred from apatite fission track thermochronology. Tectonics 14, 704-718.

Sheppard, S. M. F., Brown, P. E. \& Chambers, A. D. 1977: The Lilloise intrusion, East Greenland: hydrogen isotope evidence for the efflux of magmatic water into the contact metamorphic aureole. Contr. Mineral. Petrol. 63, 129-147.

Soper, N. J., Downie, C., Higgins, A. C. \& Costa, L. I. 1976: Biostratigraphic ages of Tertiary basalts on the East Greenland continental margin and their relationship to plate separation in the northeast Atlantic. Earth planet. Sci. Lett. 32, 149-157.

Wager, L. R. 1947: Geological investigations in East Greenland. Part IV. The stratigraphy and tectonics of Knud Rasmussens Land and the Kangerdlugssuaq region. Meddr Gronland 134(5), $64 \mathrm{pp}$.

Wager, L. R. \& Deer, W. A. 1938: A dyke swarm and crustal flexure in East Greenland. Geol. Mag. 75, 39-46.

C. K. B., Geological Institute, University of Copenhagen, $\emptyset_{\text {ster }}$ Voldgade 10, DK-1350 Copenhagen K, Denmark and Danish Lithosphere Centre, Copenhagen 